\title{
KAJIAN BERPIKIR KRITIS PADA METODE INKUIRI
}

\author{
Dwi Nugraheni Rositawati \\ Program Studi Pendidikan Fisika Universitas Sanata Dharma \\ Email : wiwikfis@gmail.com
}

\begin{abstract}
This study examines the fundamental things of the Inquiry Method that can be used to improve critical thinking skills. The purpose of this study are: a) Knowing the mechanism of the Inquiry Method can be used to improve critical thinking skills, b) Knowing the steps of critical thinking, c) Knowing the characteristics of critical thinking, d) Knowing the supporting components of the increasing critical thinking skills by applying inquiry method, and e) Knowing the role of supporting components and their influence in improving critical thinking skills by applying inquiry methods. The results of the study revealed that critical thinking consisted of six sub-abilities which became the core of critical thinking skills, namely interpretation, analysis, evaluation, inference, explanation and self regulation. The steps of the Inquiry method are the foundation for critical thinking and can be used as a "thinking map". The process of reasoning in a systematic, logical and deep manner accompanied by scientific arguments along with evidence in the form of accurate data / information so that conclusions can be used to train critical thinking. The dominant supporting component that can influence the increase in critical thinking skills using inquiry methods is motivation and learning environment.
\end{abstract}

Keywords: Inquiry method, critical thinking, map thinking, motivation

\begin{abstract}
Abstrak: Penelitian ini mengkaji hal-hal mendasar pada Metode Inkuiri yang dapat digunakan untuk meningkatkan kemampuan berpikir kritis. Tujuan dari penelitian ini adalah: a) Mengetahui mekanisme Metode Inkuiri dapat digunakan untuk meningkatkan kemampuan berpikir kritis, b) Mengetahui langkah-langkah berpikir kritis, c) Mengetahui karakteristik berpikir kritis, d) Mengetahui komponenkomponen pendukung terjadinya peningkatan kemampuan berpikir kritis dengan penerapan metode inkuiri, dan e) Mengetahui peranan komponen pendukung dan pengaruhnya dalam meningkatkan kemampuan berpikir kritis dengan penerapan metode inkuiri. Hasil penelitian mengungkapkan bahwa berpikir kritis terdiri dari enam sub-kemampuan yang menjadi inti kemampuan berpikir kritis yaitu interpretasi, analisis, evaluasi, inferensi, eksplanasi dan regulasi diri. Langkah-langkah metode Inkuiri merupakan landasan untuk berpikir kritis dan dapat digunakan sebagai "peta berpikir". Proses penalaran secara sistematis, logis dan mendalam yang disertai argumentasi ilmiah beserta bukti berupa data/informasi yang akurat sehingga diperoleh kesimpulan yang dapat dipertanggungjawabkan dapat digunakan untuk melatih berpikir kritis. Komponen pendukung yang dominan dapat mempengaruhi terjadinya peningkatan kemampuan berpikir kritis dengan menggunakan metode inkuiri adalah motivasi dan lingkungan belajar.
\end{abstract}

Kata kunci: Metode Inkuiri, berpikir kritis, peta berpikir, motivasi

\section{PENDAHULUAN}

Dewasa ini, informasi beredar dengan sangat deras. Orang dapat mengetahui berbagai informasi dari internet, media massa, televisi, radio, dan lain-lain dengan sangat mudah. Informasi yang diberikan pada masing-masing media sering kali berbeda-beda sehingga menimbulkan berbagai pemikiran yang simpang siur. Untuk itu kiranya perlu bekal dan dasar bagaimana caranya dapat memilih informasi yang dapat berguna bagi perkembangan seseorang. Hal serupa juga ditemukan di bangku pembelajaran baik di level SD, SMP, SMA 
bahkan Perguruan Tinggi. Banyaknya materi pembelajaran yang ada sekarang seringkali membuat pembelajar sendiri justru tidak menemukan makna dari pembelajaran itu sendiri. Pembelajaran banyak diterima sebagai sesuatu hal yang bersifat hafalan. Karena pembelajaran diserap secara hafalan maka ilmunya sendiri tidak bertahan lama mengendap pada diri seseorang yang belajar. Belajar seakan-akan menjadi seolah-olah hal yang sering disebut sebagai formalitas saja. Supaya pembelajar dapat sungguh-sungguh mengalami proses pembelajaran dan mengetahui inti pokok pembelajaran maka diperlukan kemampuan berpikir kritis. Kemampuan berpikir kritis diperlukan supaya dapat membantu pembelajar dalam mengelola pikiran untuk memperoleh cara belajar yang sesuai, mengetahui makna belajar dan mengetahui inti pokok pembelajaran. Seiring dengan perkembangan era informasi yang semakin pesat dan kehidupan yang semakin kompleks, kemampuan berpikir kritis dipandang sebagai suatu kompetensi dasar yang sangat diperlukan untuk dikuasai seperti halnya membaca dan menulis (Fisher, A., 2009).

Berpikir kritis menjadi istilah yang sangat menarik dibicarakan dalam dunia pendidikan pada dasawarsa terakhir walaupun sebenarnya tradisi berpikir kritis sendiri sudah lama ada dan masih terus berkembang (Fisher, A., 2009). Perkembangan tradisi berpikir kritis telah menarik minat peneliti untuk mempelajarinya (Kwan, Y. W., 2015). Hal ini juga seiiring dengan yang dikampanyekan pemerintah dimana Dirjen Dikti (Direktorat Jenderal Pendidikan Tinggi) Direktorat Pembelajaran dan Kemahasiswaan menyelenggarakan KPKM (Kompetisi Pemikiran Kritis Mahasiswa) yang merupakan media pertukaran ide, pengetahuan, dan informasi untuk mengkritisi kebijakan pemerintah dan atau rancangan kebijakan pemerintah serta saran kebijakan dan atau pembangunan (Pedoman Umum Kompetisi Pemikiran Kritis Mahasiswa Dirjen Dikti). Meskipun terdapat sejumlah teori dan pendidik yang telah mengembangkan definisi dan konseptualisasi berpikir kritis, namun studi mengenai faktor yang mempengaruhi kemampuan berpikir kritis masih terbatas (Kwan, Y. W., 2015).

Berpikir kritis perlu dikembangkan dalam pembelajaran sains supaya pembelajar dapat memahami sains dengan baik terutama supaya sains tidak dipahami hanya secara hafalan. Metode Inkuiri merupakan salah satu metode pembelajaran yang dipergunakan dalam pembelajaran sains dan dapat digunakan untuk meningkatkan kemampuan berpikir kritis. Pada prosesnya, pembelajaran perlu dirancang untuk mengoptimalkan potensi peserta didik yaitu dengan cara membantu proses rekonstruksi pengetahuan dan menjadikannya sebagai pembelajar aktif (Anggraeni, 2013) dan terbiasa mengembangkan kemampuan berpikir tingkat tinggi terlebih ketika harus mempelajari banyaknya materi pembelajaran. Hal ini sesuai dengan yang disarankan Matthew Lipman dalam Kuswana yaitu bahwa dalam belajar keterampilan berpikir seyogianya peserta didik diperlakukan sebagai seorang pemikir. Teori Vygotskian dalam Kuswana mengemukakan bahwa pendidik harus mencoba untuk membantu peserta didik terlibat dalam pemikiran tingkat yang lebih tinggi. Diharapkan pembelajaran dengan Metode Inkuiri mampu melatih peserta didik berpikir kritis yang dapat dipergunakan untuk lebih mendalami sains, melatih berpikir tingkat tingi (Gilles, R. M., 2012) dan dapat dipergunakan supaya tidak hanya mengikuti arus di Era informasi dan kehidupan yang semakin kompleks ini.

Berdasarkan uraian di atas, tujuan dari penelitian Kajian Berpikir Kritis pada Metode Inkuiri ini adalah untuk:

a) Mengetahui karakteristik berpikir kritis.

b) Mengetahui langkah-langkah berpikir kritis.

c) Mengetahui mekanisme Metode Inkuiri dapat digunakan untuk meningkatkan kemampuan berpikir kritis. 
d) Mengetahui komponen-komponen pendukung terjadinya peningkatan kemampuan berpikir kritis dengan penerapan metode inkuiri.

e) Mengetahui peranan komponen pendukung dan pengaruhnya dalam meningkatkan kemampuan berpikir kritis dengan penerapan metode inkuiri.

\section{METODE PENELITIAN}

Metode penelitian yang digunakan dalam penelitian ini adalah metode riset pustaka. Adapun alur yang digunakan adalah sebagai berikut:

a. Menentukan ide umum tentang topik penelitian

b. Mencari informasi pendukung

c. Mempertegas fokus dan mengorganisasi bahan bacaan

d. Reorganisasi bahan dan membuat catatan penelitian

e. Memperkaya bahan bacaan

f. Reorganisasi bahan dan mulai menyusun laporan

Adapun parameter-parameter yang menjadi perhatian pokok dalam mencapai tujuan penelitian ini adalah sebagai berikut:

a. Diperoleh persinggungan pada langkah-langkah inkuiri dengan langkah-langkah berpikir kritis beserta karakteristiknya sehingga diketahui hal mendasar pada metode Inkuiri yang dapat digunakan untuk meningkatkan kemampuan berpikir kritis. Dengan demikian dapat diketahui mekanisme Metode Inkuiri dapat digunakan untuk meningkatkan kemampuan berpikir kritis

b. Diketahui komponen-komponen pendukung eksternal dan internal, peranan dan pengaruhnya dalam meningkatkan kemampuan berpikir kritis dengan penerapan metode inkuiri.

\section{HASIL DAN PEMBAHASAN}

\subsection{Berpikir Kritis dan Metode Inkuiri}

Menurut Kamus Besar Bahasa Indonesia, yang dimaksud berpikir artinya menggunakan akal budi untuk mempertimbangkan dan memutuskan sesuatu, menimbang-nimbang dalam ingatan. Sedangkan kritis adalah (1) bersifat tidak dapat lekas percaya, (2) bersifat selalu berusaha menemukan kesalahan atau kekeliruan; tajam dalam menganalisis.

Kemampuan berpikir kritis sering disebut sebagai salah satu kemampuan berpikir tingkat tinggi (Peirce, 2006). Glaser menyatakan dua elemen dalam berpikir kritis yaitu memiliki keterampilan berpikir kritis dan kemauan untuk menggunakan keterampilan tersebut. Glaser menyebutkan bahwa berpikir kritis adalah sikap yang siap untuk mempertimbangkan dengan seksama masalah-masalah yang ada dalam jangkauan pengalaman seseorang atau pengetahuan tentang metode inkuiri dan bernalar yang logis dan kemampuan untuk menerapkan metode tersebut (Glaser dalam Ricketts, 2004). Richard Paul menyebutkan bahwa berpikir kritis merupakan suatu cara berpikir yang unik dan memiliki tujuan tertentu di mana pemikir secara sistematis menetapkan kriteria dan standar intelektual dalam berpikir, dalam mengonstruksi pemikiran, mengarahkan konstruksi berpikir sesuai dengan standar tertentu, dan menilai efektivitas berpikir sesuai tujuan, kriteria, dan standar berpikir (Paul dalam Ricketts, 2004). Sementara Rudd, Baker, dan Hoover mengemukakan bahwa berpikir kritis adalah suatu pendekatan yang menggunakan nalar, memiliki tujuan tertentu, dan menggunakannya untuk memecahkan masalah atau menanggapi pertanyaan dengan bukti dan informasi yang mengarah pada solusi yang sulit dibantah. 
Sedangkan definisi yang diberikan Richard Paul, berpikir kritis adalah model berpikirmengenai hal, substansi atau masalah apa saja dimana si pemikir meningkatkan kualitas pemikirannya dengan menangani secara terampil struktur-struktur yang melekat dalam pemikiran dan menerapkan standar-standar intelektual padanya. Berpikir kritis menurut Facione adalah penilaian yang terarah dan terukur yang menghasilkan interpretasi, analisis, evaluasi, dan kesimpulan, dan juga penjelasan terhadap pertimbangan-pertimbangan faktual, konseptual, metodologis, kriteriologis, atau kontekstual yang menjadi dasar penilaian tersebut. Facione juga menyebutkan bahwa kemampuan berpikir kritis memiliki dua dimensi, yaitu dimensi kognitif dan dimensi disposisi afektif. Pernyataan berpikir kritis dimulai dengan pemahaman berpikir kritis menjadi tujuan dan penilaian pengaturan diri yang menghasilkan interpretasi, analisis, evaluasi, dan kesimpulan serta penjelasan tentang bukti, konseptual, metodologi dan kriteria sebagai pertimbangan kontekstual (Facione, 1990).

Dari pendapat beberapa ahli mengenai pengertian berpikir kritis di atas, dapat dinyatakan bahwa berpikir kritis adalah suatu proses kegiatan interpretasi dan evaluasi yang terarah, jelas, terampil dan aktif tentang suatu masalah yang meliputi observasi, merumuskan masalah, menentukan keputusan, menganalisis dan melakukan penelitian ilmiah yang akhirnya menghasilkan suatu konsep. Kemampuan ini penting untuk dikembangkan pada peserta didik, mengingat kemampuan berpikir kritis mempengaruhi prestasi belajar dan membantu peserta didik memahami konsep. Berpikir kritis dapat digunakan untuk mencapai pemahaman yang mendalam tentang suatu materi atau konsep sehingga pemikiran peserta didik terhadap suatu konsep tertentu adalah valid dan benar. Berpikir kritis merupakan proses berpikir reflektif yang membutuhkan kecermatan dalam mengambil keputusan melalui serangkaian prosedural untuk menganalisis, menguji, dan mengevaluasi bukti serta dilakukan secara sadar. Adapun indikator berpikir kritis yang harus dimiliki adalah (1) Keterampilan menganalisis merupakan suatu keterampilan menguraikan sebuah struktur ke dalam komponen-komponen agar mengetahui pengorganisasian struktur tersebut. Dalam keterampilan tersebut tujuan pokoknya adalah memahami sebuah konsep global dengan cara menguraikan atau merinci globalitas tersebut ke dalam bagian-bagian yang lebih kecil dan terperinci; (2) Keterampilan mensintesis merupakan keterampilan yang berlawanan dengan keterampilan menganalisis. Keterampilan menganalisis adalah keterampilan menghubungkan bagian-bagian menjadi sebuah bentukan atau susunan yang baru; (3) Keterampilan mengenal dan memecahkan masalah, keterampilan ini merupakan keterampilan aplikatif konsep kepada beberapa pengertian baru. Keterampilan ini bertujuan agar pembaca mampu memahami dan menerapkan konsep-konsep ke dalam permasalahan atau ruang lingkup baru; (4) Keterampilan menyimpulkan ialah kegiatan akal pikiran manusia berdasarkan pengertian/pengetahuan (kebenaran) yang dimilikinya dapat beranjak mencapai pengertian/pengetahuan (kebenaran) yang baru yang lain; (5) keterampilan mengevaluasi, keterampilan ini menuntut pemikiran yang matang dalam menentukan nilai sesuatu dengan berbagai kriteria yang ada.

Metode pembelajaran inkuiri merupakan metode pembelajaran yang berupaya menanamkan dasar-dasar berpikir ilmiah pada diri pembelajar dengan melibatkan pembelajar secara aktif. Metode inkuiri membantu pembelajar untuk aktif menemukan suatu konsep tertentu melalui proses ilmiah. Proses ilmiah dapat digunakan untuk mengembangkan sikap ilmiah. Sehingga pembelajaran inkuiri yang pada dasarnya merupakan pembelajaran yang mengembangkan proses ilmiah dapat digunakan untuk mengembangkan sikap ilmiah (Dermott, 1996). Sikap ilmiah tersebut mencakup sikap ingin tahu, menghargai pembuktian, berpikir kritis, kreatif dalam memecahkan masalah, berbicara berdasarkan kepada bukti-bukti konkrit atau data, dan peduli terhadap lingkungan. "The Inquiry Teaching Model" 
menyebutkan bahwa model pembelajaran inkuiri memungkinkan pembelajar berperan sebagai "problem solver" yang merupakan kunci pemahaman yang lebih baik. Metode pembelajaran Inkuiri dapat membantu dalam menemukan konsep dasar atau ide-ide yang berkaitan dengan topik pembelajaran, mendorong untuk berpikir dan bekerja atas inisiatifnya sendiri, bersikap obyektif, jujur dan terbuka, mendorong untuk berpikir intuitif dan merumuskan hipotesisnya sendiri. Sehingga kalau pembelajar sudah dapat menemukan sendiri konsep dasar ilmunya maka akan menimbulkan kepuasan tersendiri yang pada akhirnya akan melahirkan rasa percaya diri karena dapat menemukan sesuatu secara orisinal dari dalam dirinya sendiri dan ilmu yang diperoleh tidak lagi hanya sekedar ilmu yang hanya dihafal saja. Supaya pembelajaran inkuiri sungguh-sungguh mengenai sasaran perlu diketahui standar-standar pembelajaran inkuiri. Standar-standar inkuiri menentukan kemampuan dasar yang diperlukan untuk melakukan penyelidikan dan pengetahuan yang akan membantu dalam memahami inkuiri sebagai suatu cara untuk menghasilkan pengetahuan (Ismunandar, 2000). Penggunaan Inkuiri akan berdampak pada peningkatan kualitas pembelajaran sains apabila dipahami makna dan manfaatnya. Inkuiri bermakna apabila diperlakukan sebagai kemampuan kerja ilmiah yang selalu dikembangkan, diterapkan dan diukur selama proses pembelajaran.

Metode inkuiri dipahami sebagai metode pembelajaran yang menggunakan langkahlangkah sistematis seperti orientasi, merumuskan masalah, pengajuan hipotesis, pengumpulan data melalui eksperimen, menguji hipotesa dan menarik kesimpulan. Langkah-langkah tersebut memungkinkan peserta didik untuk menemukan sendiri jawaban terhadap permasalahan yang dihadapi. Untuk pembelajaran sains sangat pentinglah para peserta didik dibiasakan untuk meneliti sendiri permasalahan yang dihadapi agar dapat menemukan sendiri jawabannya seperti halnya para ilmuwan yang melakukan penelitian terhadap suatu permasalahan untuk sampai pada suatu kesimpulan.

Kecakapan berpikir kritis merupakan kecakapan berpikir untuk menilai secara terarah dan terukur yang menghasilkan interpretasi, analisis, evaluasi, inferensi, eksplanasi, regulasi diri, dan juga penjelasan terhadap pertimbangan-pertimbangan faktual, konseptual, metodologis, kriterilogis, atau kontekstual yang menjadi dasar penilaian tersebut. Berpikir kritis merupakan kegiatan berpikir tingkat tinggi yang terdiri dari dimensi kognitif dan disposisi afektif.

Metode inkuiri menggunakan langkah-langkah yang bersinggungan langsung dengan elemen-elemen kecakapan berpikir kritis. Keduanya semestinya memiliki hubungan sebab akibat yang langsung. Sehingga metode inkuiri dapat digunakan untuk meningkatkan aspek kemampuan berpikir kritis baik dari segi kognitif maupun dari segi disposisi afektif. Pembentukan disposisi afektif biasanya membutuhkan waktu dan proses yang lebih lama karena menyangkut pembentukan sikap. Sehingga penguasaan berpikir kritis sebenarnya merupakan hal pembiasaan.

\subsection{Karakteristik dan langkah-langkah berpikir kritis}

Sejalan dengan temuan bahwa berpikir dapat ditingkatkan dengan pengalaman pendidikan yang disengaja (Higgins., 2004; Moseley et al., 2005 dalam Kwan, 2015) telah menjadi salah satu definisi yang diterima secara luas dan berpengaruh. Ennis mendefinisikan berpikir kritis sebagai " pemikiran yang wajar dan reflektif yang difokuskan pada memutuskan apa yang harus percaya atau melakukan ". Dia menyarankan 12 kemampuan berpikir kritis, dikelompokkan ke dalam empat bidang, yaitu kejelasan, dasar, inferensi, dan interaksi.

Facione (1996), mengungkapkan pemikir kritis yang ideal mempunyai kebiasaan ingin tahu, penuh kepercayaan pada alasan, berpikiran terbuka, fleksibel , berpikiran adil dalam evaluasi, jujur dalam menghadapi prasangka pribadi, bijaksana dalam membuat penilaian, 
bersedia untuk mempertimbangkan kembali, jelas tentang isu-isu, tertib dalam hal yang kompleks, rajin mencari informasi yang relevan, wajar dalam pemilihan kriteria, fokus dalam penyelidikan, dan gigih dalam mencari hasil. Sehingga dapat dituliskan karakteristik berpikir kritis sebagai berikut:

- Rasa ingin tahu berkaitan dengan berbagai masalah

- Perhatian untuk menjadi lebih baik

- Kewaspadaan terhadap kesempatan untuk menggunakan pemikiran kritis

- Kepercayaan dalam proses pencarian/ inkuiri

- Kepercayaan pada kemampuan sendiri seseorang

- Keterbukaan diri terhadap pandangan dunia yang berbeda

- Fleksibilitas dalam mempertimbangkan alternatif dan opini

- Pemahaman tentang pendapat orang lain

- Kehati-hatian dalam menangguhkan, membuat atau mengubah penilaian

- Kesediaan untuk mempertimbangkan kembali dan merevisi pandangan

- Kejujuran dalam menghadapi prasangka, stereotip, atau kecenderungan egosentris

- Kehati-hatian dalam menangguhkan, membuat atau mengubah penilaian

- Kesediaan untuk mempertimbangkan kembali dan merevisi pandangan berdasarkan refleksi.

Menurut Facione (2007), berpikir kritis terdiri dari enam sub-kemampuan yang menjadi inti kemampuan berpikir kritis yaitu:

a. Interpretasi

Interpretasi merupakan proses memahami dan mengungkapkan makna atau arti berbagai jenis pengalaman, situasi, data, peristiwa, penilaian, konvensi, keyakinan, aturan, prosedur atau kriteria. Interpretasi meliputi sub kemampuan kategorisasi, menguraikan arti dan klarifikasi arti.

b. Analisis

Analisis adalah proses mengidentifikasi maksud dan hubungan antar pernyataan, pertanyaan, konsep, deskripsi atau bentuk lain yang menyatakan keyakinan, penilaian, pengalaman, alasan, informasi, atau pendapat. Sub kemampuan analisis adalah menguji pendapat, mendeteksi dan menganalisa alasan.

c. Evaluasi

Evaluasi merupakan suatu proses pengkajian kredibilitas pernyataan deskripsi persepsi, pengalaman, situasi, penilaian, keyakinan atau opini seseorang serta mengkaji kekuatan logis dari hubungan aktual antara dua atau lebih pernyataan, deskripsi, pertanyaan atau bentuk representasi lainnya. Sub kemampuan evalusi adalah menaksir/ menetapkan pernyataan atau alasan.

d. Inferensi

Inferensi merupakan proses mengidentifikasi dan memperoleh unsur yang dibutuhkan untuk menarik kesimpulan, untuk membentuk suatu dugaan atau hipotesis, mempertimbangkan informasi yang relevan dan mengembangkan konsekuensi yang sesuai dengan data, pernyataan, prinsip, bukti, penilaian, keyakinan, opini, konsep, deskripsi, pertanyaan dan bentuk-bentuk representasi lainnya. Sub kemampuan inferensi adalah menanyakan fakta/ keterangan/ bukti, memperkirakan alternatif, dan menggambarkan kesimpulan. 
e. Eksplanasi

Eksplanasi diartikan sebagai suatu kemampuan untuk mempresentasikan hasil penilaian seseorang dengan cara meyakinkan dan koheren. Sub kemampuan eksplanasi adalah menetapkan hasil, menyuguhkan prosedur, menunjukkan alasan

f. Pengaturan diri/regulasi diri

Pengaturan diri adalah kesadaran diri untuk memantau aktivitas kognitif, unsur-unsur yang digunakan dalam aktivitas tersebut, dan hasil-hasil yang dikembangkan, terutama melalui penggunaan keterampilan dalam menganalisis, mengevaluasi penilaian inferensial seseorang dengan suatu pendangan melalui pengajuan pertanyaan, konfirmasi, validasi, atau pembetulan terhadap hasil penilaian seseorang. Sub kemampuan regulasi diri adalah pengujian/ pemeriksaan diri dan koreksi diri.

Langkah-langkah berpikir kritis adalah:

1. Mengenali masalah

Identifikasi terhadap masalah adalah langkah pertama yang sangat penting.

2. Mengumpulkan dan menyusun informasi yang diperlukan.

Pengetahuan luas dan informasi penting terkait masalah sangat dibutuhkan untuk menilai sesuatu secara tepat dan akurat.

3. Mengevaluasi data, fakta, serta pernyataan-pernyataan.

4. Mengenali asumsi-asumsi.

5. Mencermati hubungan logis antara masalah dan jawaban.

6. Menggunakan bahasa yang tepat, jelas dan khas.

7. Menemukan cara-cara untuk menangani masalah.

Temukan cara-cara kreatif untuk menangani masalah.

8. Menarik kesimpulan/pendapat dari isu atau persoalan yang dibahas.

\subsection{Mekanisme Metode Inkuiri untuk meningkatkan kemampuan berpikir kritis}

Dalam pembelajaran inkuiri, belajar bukan hanya mengingat sejumlah fakta, akan tetapi belajar adalah proses berpikir (learning how to think). Metode Inkuiri memberikan peluang kepada peserta didik untuk memaksimalkan aktivitas belajarnya. Berdasarkan sintaks dalam Metode Inkuiri sangat mendukung proses berpikir tingkat tinggi. Pada tahap ini pendidik melakukan langkah untuk membina suasana atau iklim pembelajaran yang kondusif. Hal yang dilakukan dalam tahap orientasi ini adalah:

a. menjelaskan topik, tujuan, dan hasil belajar/ kemampuan yang diharapkan dapat dicapai oleh peserta didik

b. menjelaskan pokok-pokok kegiatan yang harus dilakukan oleh peserta didik untuk mencapai tujuan. Pada tahap ini dijelaskan langkah-langkah inkuiri serta tujuan setiap langkah, mulai dari langkah merumuskan masalah sampai dengan merumuskan kesimpulan

c. menjelaskan pentingnya topik dan kegiatan belajar. Hal ini dilakukan dalam rangka memberikan motivasi belajar peserta didik.

Merumuskan masalah merupakan langkah awal yang dapat digunakan untuk menantang peserta didik untuk berpikir memecahkan suatu masalah. Proses pencarian jawaban itulah yang sangat penting dalam metode inkuiri, oleh sebab itu melalui proses tersebut peserta didik akan memperoleh pengalaman yang sangat berharga sebagai upaya mengembangkan mental melalui proses berpikir.

Dalam tahapan observasi, observasi dapat dilakukan dengan baik bila dilandasi dengan kemampuan berpikir secara sistematis, kritis, dan analitis dengan mengikuti pola-pola metode 
ilmiah. Setelah tahap observasi, peserta didik dapat mengajukan pertanyaan berdasarkan observasi yang dilakukan.

Perumusan pertanyaan yang diajukan peserta didik akan merangsang kemampuan berpikir kritis peserta didik dalam merumuskan masalah. Dalam perumusan masalah, peserta didik akan mengoptimalkan pengetahuan awal yang dimiliki dengan cara mengingat kembali konsep-konsep terkait dengan kegiatan observasi yang dilakukan yang akan memberikan dampak positif akan lebih memperkuat konsep-konsep tersebut dalam memori jangka panjang. Proses belajar yang dimulai dengan merumuskan masalah, mencari, menyelidiki dan menemukan sendiri jawaban dari suatu masalah yang dipertanyakan, akan memberikan kesempatan belajar yang lebih bermakna pada peserta didik. Dengan demikian pengetahuan dan keterampilan yang diperoleh, bukan dari mengingat atau menghafal seperangkat fakta, konsep, atau teori, tetapi dapat menemukan dan membangun atau mengkontruksi sendiri pengetahuan itu dan memberi makna melalui pengalaman nyata.

Tahap Pengajuan hipotesis terkait dengan permasalahan yang dirumuskan. Keterampilan berpikir kritis dan berpikir deduktif yang diperlukan berkaitan dengan pengumpulan data yang berkaitan dengan hipotesis. Hipotesis adalah jawaban sementara dari suatu permasalahan yang dikaji. Sebagai jawaban sementara, hipotesis perlu diuji kebenarannya. Salah satu cara yang dapat dilakukan pendidik untuk mengembangkan kemampuan menebak (berhipotesis) pada setiap anak adalah dengan mengajukan berbagai pertanyaan yang dapat mendorong peserta didik untuk dapat merumuskan jawaban sementara atau dapat merumuskan berbagai perkiraan kemungkinan jawaban dari suatu permasalahan yang dikaji.

Tahap pengumpulan data, kemampuan berpikir kritis peserta didik akan lebih berkembang melalui pencarian sumber atau informasi yang relevan dengan rumusan masalah dan hipotesis yang dibuat. Proses pencarian informasi atau sumber yang relevan merupakan proses investigasi secara teoritik dari kemampuan berpikir kritis. Investigasi informasi yang relevan terkait dengan hipotesis yang diajukan akan memberikan kemampuan kepada peserta didik untuk menemukan sendiri jawabannya dan berpikir secara logis atau rasional dalam bentuk membandingkan, mengklasifikasikan, menunjukkan interaksi sebab-akibat, berpikir secara deduktif dan induktif, kemampuan memberikan analogi, serta mengkritisi informasi yang diperoleh yang semuanya akan bermuara pada peningkatan kemampuan berpikir kritis peserta didik. Mengumpulkan data merupakan aktivitas untuk menjaring informasi yang dibutuhkan untuk menguji hipotesis yang diajukan. Dalam pembelajaran inkuiri, mengumpulkan data merupakan proses mental yang sangat penting dalam pengembangan intelektual. Proses pengumpulan data bukan hanya memerlukan motivasi yang kuat dalam belajar, akan tetapi juga membutuhkan ketekunan dan kemampuan menggunakan potensi berpikirnya. Menguji hipotesis adalah menentukan jawaban yang dianggap diterima sesuai dengan data atau informasi yang diperoleh berdasarkan pengumpulan data. Menguji hipotesis juga berarti mengembangkan kemampuan berpikir rasional. Artinya, kebenaran jawaban yang diberikan bukan hanya berdasarkan argumentasi, akan tetapi harus didukung oleh data yang ditemukan dan dapat dipertanggungjawabkan. Menurut para ahli, melatih berpikir kritis dapat dilakukan dengan cara mempertanyakan apa yang dilihat dan didengar. Setelah itu, dilanjutkan dengan bertanya mengapa dan bagaimana tentang hal tersebut.

Tahap penyimpulan, peserta didik akan melibatkan berbagai aspek dalam kemampuan berpikir kritis yaitu berpikir logis, proses induktif, deduktif, evaluatif, memberikan argumen yang logis dalam pengambilan keputusan. Seluruh aspek tersebut akan terakomodasi dalam diskusi interaktif saat masing-masing kelompok menyampaikan hasil pengamatan dan 
diskusinya. Menarik kesimpulan mengembangkan sikap ilmiah, yakni obyektif, jujur, hasrat ingin tahu, terbuka, berkemauan, dan tanggung jawab.

\subsection{Komponen-komponen pendukung eksternal dan internal, peranan dan pengaruhnya dalam meningkatkan kemampuan berpikir kritis dengan penerapan metode inkuiri}

Menurut Kort (1987), motivasi merupakan hasil faktor internal dan eksternal. Motivasi adalah upaya untuk menimbulkan rangsangan, dorongan ataupun pembangkit tenaga seseorang agar mau berbuat sesuatu atau memperlihatkan perilaku tertentu yang telah direncanakan untuk mencapai tujuan yang telah ditetapkan. Menciptakan minat adalah cara yang sangat baik untuk memberi motivasi pada diri demi mencapai tujuan. Motivasi yang tinggi terlihat dari kemampuan atau daya serap dalam belajar, mengambil resiko, menjawab pertanyaan, menentang kondisi yang tidak mau berubah ke arah yang lebih baik, semakin cepat memperoleh tujuan, memperlihatkan tekad diri, sikap konstruktif, serta memperlihatkan hasrat dan keingintahuan.

Pendekatan instruksional yang menekankan bahwa lingkungan konstruktivis dan pendekatan pembelajaran yang berpusat pada peserta didik mampu mengembangkan berpikir kritis peserta didik. (Bransford dkk., 1999) menyarankan bahwa pendidik yang efektif menggunakan strategi yang memperhatikan empat unsur: peserta didik, pengetahuan, penilaian, dan komunitas. Lingkungan yang berpusat pada pembelajar memberi perhatian yang besar pada pengetahuan, keterampilan, sikap, dan keyakinan yang pelajar bawa ke lingkungan pendidikan. Lingkungan berpusat pengetahuan membantu peserta didik mengorganisasi pengetahuan dan mengatur pengetahuan itu sehingga mendukung perencanaan dan berpikir strategis.

Lingkungan berpusat penilaian membantu peserta didik belajar untuk memantau dan mengatur pembelajaran. Lingkungan ini memberikan para peserta didik kesempatan untuk mendapatkan umpan balik dan revisi. Lingkungan berpusat penilaian juga membantu pendidik dalam mengatur kegiatan kelas, mendiagnosis gagasan dan produk peserta didik, dan juga keputusan pendidik (Duschl dan Gitomer, 1997; Gitomer dan Duschl, 1995).

Lingkungan berpusat komunitas mengharuskan peserta didik untuk mengartikulasikan gagasan-gagasan mereka, menantang gagasan orang lain, dan saling menegosiasikan makna yang lebih dalam bersama peserta didik lain. Lingkungan seperti ini mendorong orang untuk belajar satu sama lain. Mereka menghargai proses pencarian untuk pemahaman dan mengakui bahwa kesalahan adalah tahap yang diperlukan jika ingin terjadi proses pembelajaran. Lebih lanjut, lingkungan tersebut terbuka pada gagasan-gagasan dan cara berpikir baru, karena anggota komunitas tersebut saling mendorong dan saling mengharapkan umpan balik, dan bekerja menggunakan gagasan-gagasan baru ke dalam pemikiran mereka.

Pembelajaran berbasis inkuiri memerlukan perhatian penuh untuk menciptakan lingkungan belajar dan pengalaman-pengalaman yang membuat para peserta didik dapat memperbandingkan gagasan-gagasan baru, memperdalam pemahaman mereka, serta belajar untuk berpikir secara logis dan kritis mengenai dunia di sekitar mereka.

Berdasarkan uraian di atas maka dapat dituliskan alasan-alasan metode Inkuri dapat digunakan untuk meningkatkan kemampuan berpikir kritis adalah sebagai berikut:

- Langkah-langkah metode Inkuiri merupakan landasan untuk berpikir kritis

- Langkah-langkah metode Inkuiri merupakan semacam "peta berpikir"

- Pada proses menganalisa data menuju kesimpulan, peserta didik belajar menalar yang merupakan komponen berpikir kritis. Kesimpulan yang diperoleh didukung oleh 
argumentasi ilmiah yang dapat dipertangung-jawabkan, yang memiliki argumentasi yang kuat keabsahannya, didukung oleh data dan atau informasi akurat.

- Berpikir sistematis, runtut mempengaruhi berpikir kritis

- Pada langkah Inkuiri, tidak penting hanya menjalani langkah-langkah inkuiri. Yang terpenting adalah pengupasan secara mendalam terhadap argumen-argumen dengan bukti untuk dapat memperoleh kesimpulan. Atau dapat dikatakan bahwa tidak cukup bahwa pembelajaran berisi langkah-langkah Inkuiri.

- Berfikir logis dan analitis ini sangat erat kaitannya dengan kemampuan berfikir kritis untuk menjadi dasar pengambilan keputusan dan menyelesaikan masalah secara bertangung jawab.

- Berpikir kritis merupakan berpikir reflektif, sehingga perlu adanya usaha yang disadari oleh masing-masing pribadi/ peserta didik, peserta didik perlu diaktifkan untuk menyadari proses yang akan berlangsung sehingga akhirnya proses rekonstruksi dapat terjadi. Karena pada dasarnya adalah proses rekonstruksi, maka faktor-faktor yang mempengaruhi proses terjadinya konstruksi itu diperhatikan.

\section{KESIMPULAN}

Berdasarkan uraian di atas, maka dapat disimpulkan bahwa Metode Inkuiri dapat digunakan untuk membantu peserta didik terlibat dalam tingkat berpikir dan belajar yang lebih tinggi yaitu dapat meningkatkan kemampuan berpikir kritis. Berpikir kritis terdiri dari enam sub-kemampuan yang menjadi inti kemampuan berpikir kritis yaitu interpretasi, analisis, evaluasi, inferensi, eksplanasi dan regulasi diri.

Langkah-langkah metode Inkuiri merupakan landasan untuk berpikir kritis dan dapat digunakan sebagai "peta berpikir". Proses penalaran secara sistematis, logis dan mendalam yang disertai argumentasi ilmiah beserta bukti berupa data/informasi yang akurat sehingga diperoleh kesimpulan yang dapat dipertanggungjawabkan dapat digunakan untuk melatih berpikir kritis.

Komponen pendukung yang dominan dapat mempengaruhi terjadinya peningkatan kemampuan berpikir kritis dengan menggunakan metode inkuiri adalah motivasi dan lingkungan belajar.

\section{DAFTAR PUSTAKA}

Anggraeni. 2013. Implememtasi Strategi Pembelajaran Inkuiri Terhadap Kemampuan Berpikir Kritis dan Pemahaman Konsep IPA Siswa SMP. E-Journal Program Pascasarjana Universitas Pendidikan Ganesha Program Studi IPA Volume 3 Tahun 2013.

Dermott, LC. 1996. Physics by Inquiry. John Willey \& Sons.

Dunne, G. 2015. Beyond critical thinking to critical being: Criticality in higher education and life. International Journal of Education Research.

Facione, P.A. 2007. Critical Thinking: A statement of Expert Consensus for Purposes of Educational Assessment and Introduction/ The Delphi Report. Diunduh dari http:// www.insightassessment.com/pdf_files/DEXadobe.PDF.

Facione, P.A. 2007. Critical thinking: What It Is and Why It Counts. Diunduh dari http://www.insightassessment.com/pdf_files/what\&why2006.pdf.

Facione, N.C., Facione, P.A., 1996. Externalizing the Critical Thinking in Knowledge 
Development and Clinical Judgement. Diunduh dari http://www.insightassessment.com/pdf_files/Exernalizing\%20CT_\%20Nsg\%20Otlk \%201996.PDF.

Fisher, A. 2009. Berpikir Kritis Sebuah Pengantar. Jakarta: Erlangga.

Gilles, R.M., Nicholas, K., Burgh, G., Haynes, M. 2012. The effects of two strategic and meta-cognitive questioning approaches on children's explanatory behaviour, problem solving, and learning during cooperative, inquiry-based science. International Journal of Education Research.

Kamus Besar Bahasa Indonesia, Departemen Pendidikan dan Kebudayaan. Jakarta: Balai Pustaka. 1989.

Kwan, Y. W., Wong, A. F. L. 2015. Effects of the constructivist learning environment on students' critical thinking ability: Cognitive and motivational variabels as mediators. International Journal of Educational Research.

Nuryani, YR. 2005. Perkembangan Penelitian Pembelajaran Berbasis Inkuiri Dalam Pendidikan Sains. Bandung: UPI.

Olson, Steve. 2013. Inkuiri dan Standar-standar Pendidikan Sains Nasional. Sebuah Panduan untuk Pengajaran dan Pembelajaran. Bandung: SEAMEO QITEP in Science.

Pedoman Umum Kompetisi Pemikiran Kritis Mahasiswa Dirjen Dikti. 2013

Sanjaya, W. 2008. Strategi pembelajaran. Jakarta: Kencana.

Suparno, P. (1997). Filsafat Konstruktivisme dalam Pendidikan. Yogyakarta: Kanisius.

Suparno, P. (2007). Metodologi pembelajaran fisika konsruktivistik \& menyenangkan. Yogyakarta: Universitas Sanata Dharma. 